\title{
EOMES wt Allele
}

National Cancer Institute

\section{Source}

National Cancer Institute. EOMES wt Allele. NCI Thesaurus. Code C102928.

Human EOMES wild-type allele is located 3p24.1 and is approximately $7 \mathrm{~kb}$ in leng th. This allele, which encodes eomesodermin homolog protein, is involved in both embryonic development and the regulation of gene transcription. 